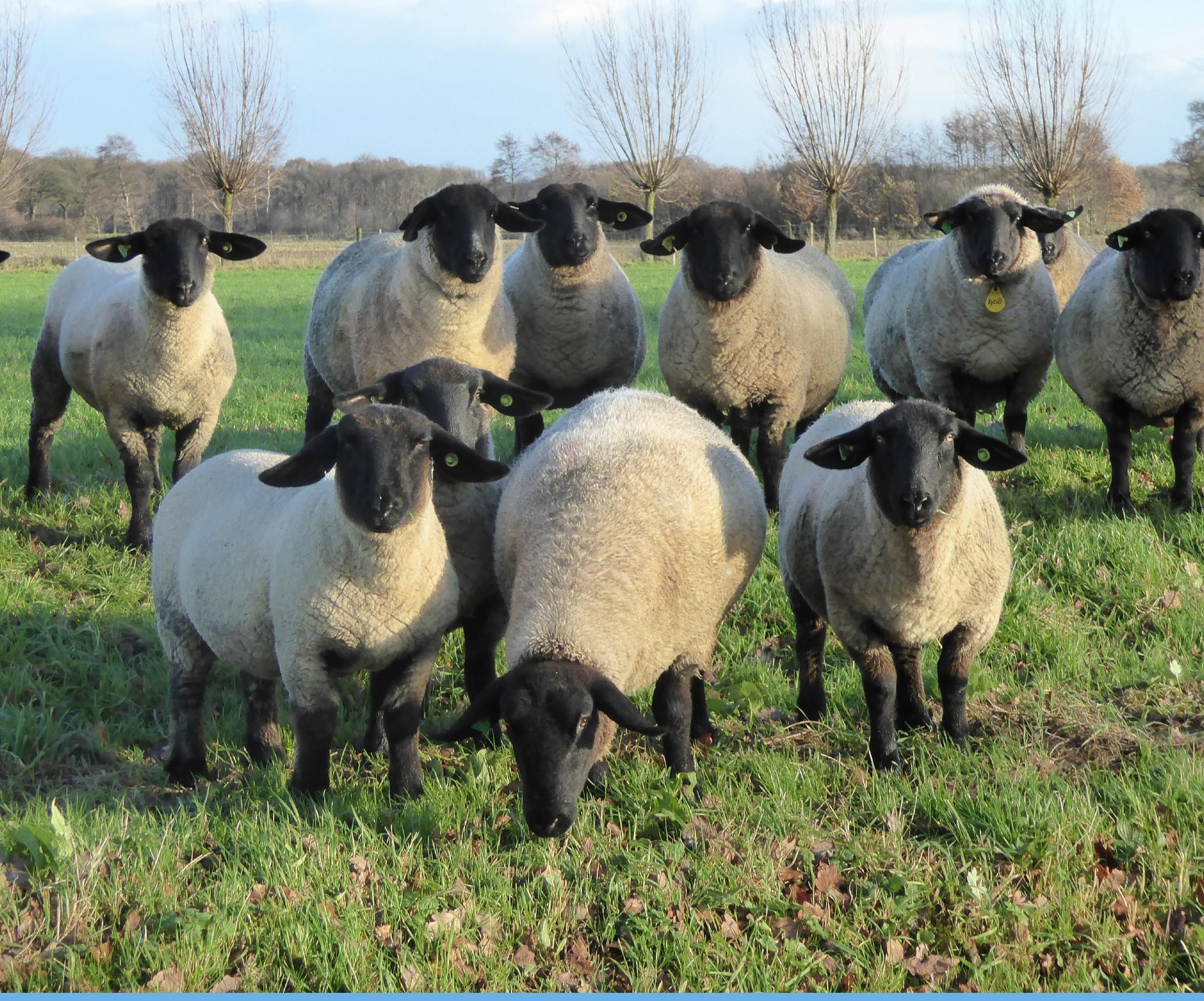

Evaluatie fokprogramma voor kortere staarten bij schapenrassen met ontheffing van het coupeerverbod

Jack J. Windig, Jan ten Napel, Rita Hoving 



\section{Evaluatie fokprogramma voor kortere staarten bij schapenrassen met ontheffing van het coupeerverbod}

Jack J. Windig, Jan ten Napel, Rita Hoving

Wageningen UR Livestock Research, Animal Breeding and Genomics

Dit onderzoek is uitgevoerd door Wageningen Livestock Research, in opdracht van en gefinancierd door het M Ministerie van Landbouw, Natuur en Voedselkwaliteit, in het kader van het Beleidsondersteunend onderzoek thema Dierenwelzijn (projectnummer BO-20-008-040 Add Q2 Tweede evaluatie fokken op staartlengte)

Wageningen Livestock Research

Wageningen, december 2017

Rapport 1074 
Windig, J.J., J. ten Napel, R. Hoving, 2017. Evaluatie fokprogramma voor kortere staarten bij schapenrassen met ontheffing van het coupeerverbod. Wageningen Livestock Research, Rapport 1074.

\section{Samenvatting}

Drie schapenrassen, Suffolk, Hampshire Down en Clun Forest, hebben een tijdelijke ontheffing van het coupeerverbod van staarten kort na de geboorte gekregen op voorwaarde dat zij fokken voor kortere staarten. In dit rapport worden de fokprogramma's bij de drie rassen en de resultaten daarvan geëvalueerd. Bij alle drie de rassen is fokwaardeschatting, nodig om duurzaam tot kortere staarten te komen, opgezet. Bij de Suffolk en Clun Forest heeft dit daadwerkelijk tot zo'n $2 \mathrm{~cm}$ kortere staarten geleid. Bij alle drie de schapenrassen is de gemiddelde staartlengte nu een kleine $17 \mathrm{~cm}$.

\section{Summary}

Three sheep breeds have in the Netherlands an temporary exempt from the ban on tail docking. In this report the breeding policy of the past decade is evaluated. All three herd books have set up breeding value estimation. This is done most effectively for the Suffolk and the Clun Forest, both breeds have lowered the mean tail length at birth to about $17 \mathrm{~cm}$, and this is about $2 \mathrm{~cm}$ less.

Dit rapport is gratis te downloaden op https://doi.org/10.18174/429684 of op www. wur.nl/livestockresearch (onder Wageningen Livestock Research publicaties).

\section{(c) 2017 Wageningen Livestock Research}

Postbus 338, 6700 AH Wageningen, T 03174839 53, E info.livestockresearch@wur.nl, www.wur.nl/livestock-research. Wageningen Livestock Research is onderdeel van Wageningen University \& Research.

Wageningen Livestock Research aanvaardt geen aansprakelijkheid voor eventuele schade voortvloeiend uit het gebruik van de resultaten van dit onderzoek of de toepassing van de adviezen.

Alle rechten voorbehouden. Niets uit deze uitgave mag worden vermenigvuldigd en/of openbaar gemaakt worden door middel van druk, fotokopie, microfilm of op welke wijze dan ook zonder voorafgaande toestemming van de uitgever of auteur.

Foto kaft: Suffolks. Foto Walter Liebregts. onderzoeksopdrachten zijn de Algemene Voorwaarden van de Animal Sciences Group van toepassing. Deze zijn gedeponeerd bij de Arrondissementsrechtbank Zwolle. 


\section{Inhoud}

$\begin{array}{ll}\text { Voorwoord } & 5\end{array}$

$\begin{array}{ll}\text { Samenvatting } & 7\end{array}$

$\begin{array}{ll}\text { Summary } & 8\end{array}$

1

$\begin{array}{ll}\text { Inleiding } & 9\end{array}$

$\begin{array}{lll}1.1 & \text { Doelstelling } & 9\end{array}$

2

$\begin{array}{ll}\text { Materiaal en methoden } & 10\end{array}$

$\begin{array}{lll}2.1 & \text { Ervaringen in het veld } & 10\end{array}$

$\begin{array}{lll}2.2 & \text { Technische evaluatie fokprogramma } & 10\end{array}$

2.2.1 Metingen aan staartlengte 10

2.2.2 Trends in staartlengte 10

$\begin{array}{ll}2.2 .3 \text { Selectieintensiteit } & 11\end{array}$

$\begin{array}{ll}2.2 .4 \text { Ingezette dieren } & 12\end{array}$

3

$\begin{array}{lll}3.1 & \text { Ervaringen in het veld } & 13\end{array}$

3.2 Technische evaluatie $\quad 14$

3.2.1 Metingen aan staartlengte $\quad 14$

$\begin{array}{ll}3.2 .2 \text { Trends in staartlengte } & 17\end{array}$

$\begin{array}{ll}3.2 .3 \text { Ingezette dieren } & 21\end{array}$

4 Discussie $\quad 23$

4.1 Clun Forest $\quad 23$

4.2 Hampshire Down $\quad 23$

$\begin{array}{lll}4.3 & \text { Suffolk } & 24\end{array}$

$\begin{array}{lll}4.4 & \text { Het gewenste einddoel } & 24\end{array}$

4.5 Aanbevelingen om programma aan te scherpen $\quad 24$

5

$\begin{array}{ll}\text { Conclusie } & 26\end{array}$

$\begin{array}{ll}\text { Literatuur } & \mathbf{2 7}\end{array}$

$\begin{array}{lll}\text { Bijlage } 1 & \text { Belscript random steekproef onder fokkers } & 28\end{array}$ 



\section{Voorwoord}

Sedert 1 januari 2008 is het in Nederland bij wet verboden om de staart van lammeren in te korten. Om mogelijke nadelige gevolgen te voorkomen hebben drie langstaartige schapenrassen, Suffolk, Hampshire Down en Clun Forest een tijdelijke ontheffing hierop gekregen. De voorwaarde is wel dat ze in de fokkerij met gerichte selectie op staartlengte het couperen proberen overbodig maken.

Voor u ligt een rapport dat de invulling van het fokbeleid van de afgelopen 5 jaar (2013-2017) evalueert. Dit rapport is gemaakt in opdracht van het Ministerie van Landbouw, Natuur en Voedselkwaliteit, Afdeling Dierenwelzijn Landbouwhuisdieren en is samen met een vertegenwoordiging van Clun Forest Schapenvereniging in Nederland, Hampshire Down Nederland en Suffolk Stamboek Nederland tot stand gekomen. Met dank voor ieders inbreng.

Dit rapport benadrukt nogmaals het belang van een goed fokprogramma met een gericht fokdoel.

Prof dr Roel Veerkamp

Afdelingshoofd Animal Breeding and Genomics

Wageningen UR Livestock Research 


\section{Samenvatting}

Drie schapenrassen, Suffolk, Hampshire Down en Clun Forest, hebben een tijdelijke ontheffing van het coupeerverbod van staarten bij lammeren gekregen op voorwaarde dat zij fokken voor kortere staarten, zodat couperen niet meer nodig zal zijn. Selectie hierop is mogelijk maar alleen effectief indien er voldoende dieren worden gemeten en er voldoende geselecteerd wordt. In dit rapport worden de fokprogramma's bij de drie rassen en de resultaten daarvan geëvalueerd. Bij alle drie de rassen is fokwaardeschatting, nodig om duurzaam tot kortere staarten te komen, opgezet. Bij de Suffolk en Clun Forest heeft dit daadwerkelijk tot zo'n $2 \mathrm{~cm}$ kortere staarten geleid. Bij alle drie de schapenrassen is de gemiddelde staartlengte nu een kleine $17 \mathrm{~cm}$. De fokprogramma's moeten worden voortgezet om de staarten verder te verkorten tot een lengte waarvoor couperen overbodig wordt. Bij de Hampshire Down moeten maatregelen worden genomen om het fokprogramma te laten werken. De andere twee rassen kunnen doorgaan op de ingeslagen weg. Aanbevelingen om de fokprogramma's verder te verbeteren worden gegeven. 


\section{Summary}

Three sheep breeds have in the Netherlands an temporary exempt from the ban on tail docking, with the obligation that an effective breeding policy for shorter tails is implemented. In this report the breeding policy of the past decade is evaluated. All three herd books have set up breeding value estimation. This is done most effectively for the Suffolk and the Clun Forest, both breeds have lowered the mean tail length at birth to about $17 \mathrm{~cm}$, and this is about $2 \mathrm{~cm}$ less. For the Hampshire Down others measures have to been taken to let the breeding program work, since there is no change. Recommendations are given. 


\section{$1 \quad$ Inleiding}

Sinds 1 januari 2008 geldt in Nederland een verbod op het couperen van staarten bij lammeren. Dit besluit is genomen na uitvoerig onderzoek of het in de Nederlandse situatie mogelijk is om met goed management verantwoord niet gecoupeerde schapen te houden (Pijpers et al. 2006). De voornaamste conclusie was dat couperen over het algemeen geen invloed heeft op het voorkomen van myiasis en andere maatregelen effectiever zijn in het terugdringen van myiasis. Er zijn echter rassen van Engelse oorsprong met langere en meer bewolde staarten dan andere schapenrassen, waar myiasis problemen groter zijn dan in andere rassen. Staarten van schapen van deze rassen worden vrijwel zonder uitzondering gecoupeerd in Engeland (Windig 2007). Met behulp van een fokprogramma kan de staartlengte verkort worden zodat in de toekomst couperen overbodig zal worden (Windig et al. 2009).

Drie van oorsprong Engelse rassen, Suffolk, Hampshire Down en Clun Forest, hebben een tijdelijke ontheffing van het coupeerverbod gekregen, omdat: .

- Zij beschikken over relatief lange en bewolde staarten, waardoor de achterhand sneller bevuild raakt en de kans op myiasis groter is.

- $\quad$ Zij in het land van herkomst (Groot-Brittannië) onder met Nederland vergelijkbare omstandigheden worden gehouden en daar standaard gecoupeerd worden.

- Er genetische variatie is en een vrij grote populatie in Nederland waardoor door middel van een fokprogramma de staartlengte verkort kan worden zodat in de toekomst de reden voor couperen kan vervallen (Windig 2007).

Als voorwaarde is gesteld dat de uitzondering tijdelijk is en dat de stamboeken daadwerkelijk fokken voor kortere staarten. In 2009 is de uitgangspositie voor wat betreft de staartlengte beschreven en zijn aanbevelingen gedaan om een fokprogramma op te zetten. In 2012 is het fokprogramma bij de drie rassen geëvalueerd (Windig et al. 2012). De conclusie was dat fokwaardeschatting bij de drie rassen was opgezet zodat selectie voor kortere staarten mogelijk was geworden. Verkorting van staartlengte bij de Suffolk was al op gang was gekomen, maar nog niet bij de andere twee rassen. Verkorting van staartlengte tot $10 \mathrm{~cm}$ binnen 15 jaar was bij alle drie de rassen mogelijk.

\section{$1.1 \quad$ Doelstelling}

Doel van dit rapport is om de stand van zaken in 2017 voor wat betreft de fokkerij voor kortere staarten bij de Clun Forest, Hampshire Down en Suffolk schapen te evalueren, als basis voor verdere beslissingen rond de fokkerij en ontheffing van het coupeerverbod.

De volgende punten komen hierbij aan de orde:

- Hoe hebben schapenhouders zelf het fokprogramma ervaren?

- Wat is de werkwijze die de stamboeken hebben gevolgd om inhoud te geven aan een programma voor fokkerij van kortere staarten?

- Hoeveel dieren zijn gemeten en wat was de ontwikkeling van de staartlengte in de afgelopen jaren?

- Wat is de ontwikkeling van de genetische aanleg (fokwaarde) voor staartlengte in de afgelopen jaren?

- Wat is de selectiedruk op staartlengte de afgelopen jaren geweest, en welke dieren zijn ingezet in de fokkerij? 


\section{Materiaal en methoden}

\subsection{Ervaringen in het veld}

Ervaringen van fokkers zijn onderzocht door middel van interviews onder een steekproef van 5 fokkers per ras. De 5 fokkers zijn als volgt gekozen. De allerkleinste fokkers, die gezamenlijk minder dan $10 \%$ van het totaal aantal dieren van het ras houden, zijn buiten beschouwing gelaten. Daarna is het aantal fokkers door 5 gedeeld. De lijsten werden gesorteerd op aantal dieren en daarna werd bij de Clun Forest elk $5^{\mathrm{e}}$ telefoonnummer gebeld, bij de Hampshire Down elk $10^{\mathrm{e}}$, en bij de Suffolk elk $12^{\mathrm{e}}$ telefoonnummer van de lijst. Lukte het niet om na drie keer bellen iemand aan de telefoon te krijgen, of wilde hij/zij niet, dan werd het volgende telefoonnummer gepakt. Interviews vonden telefonisch plaats (belscript in Bijlage I).

\subsection{Technische evaluatie fokprogramma}

\subsubsection{Metingen aan staartlengte}

Om een betrouwbaar fokprogramma op te kunnen zetten moeten in de eerste plaats gedurende een aantal jaren metingen worden gedaan aan zoveel mogelijk lammeren. Daarom is gekeken hoeveel lammeren er per jaar in de afgelopen 9 jaar zijn gemeten. De metingen zijn verricht door de houders zelf. De betrouwbaarheid van deze metingen kan niet direct worden nagegaan. Indirect kan worden nagegaan of de relatie met geboortegewicht is als verwacht. Bij grotere en zwaardere dieren kan gemiddeld genomen ook een langere staart worden verwacht. Daarom is de staartlengte tegen het geboortegewicht uitgezet zodat eventuele uitbijters konden worden vastgesteld.

\subsubsection{Trends in staartlengte}

\subsubsection{Werkelijke staartlengte}

De staartlengte en geboortegewicht wordt gemeten door de houders. De stamboeken hebben hiervoor een meetprotocol. De gegevens worden doorgegeven aan het stamboek bij de geboortemelding. De stamboeken hebben deze gegevens verzameld en gekoppeld aan andere diergegevens, zoals geboortedatum, fokker, sekse en afstamming. Deze gekoppelde informatie is voor dit onderzoek ter beschikking gesteld.

\subsubsection{Fokwaarde}

De stamboeken maken gebruik van een externe partij om elk jaar fokwaardes te schatten op basis van de gemten staartlengtes en geboortegewichten. Het Clun Forest stamboek laat NSFO de fokwaarden schatten. Het Suffolk stamboek maakt gebruik van de diensten van CRV en het Hampshire Down stamboek heeft met beide organisaties gewerkt voor de jaarlijkse fokwaardenschatting.

Om de trend in genetische aanleg voor staartlengte te kunnen schatten zijn de fokwaardes opnieuw berekend. Bij de berekening hiervan werd er van uitgegaan dat de staartlengte van het dier de som is van verschillende effecten. Om deze te schatten is het volgende model gebruikt: 
Staartlengte $=$ bedrijf/jaareffect + effect geslacht + effect worpgrootte + effect geboortegewicht + genetische aanleg + worp van geboorte + rest term

Verklaring:

Staartlengte

= Lengte gemeten binnen twee weken na geboorte;

Bedrijf/jaar effect = Bedrijf waar dier geboren en jaar waarin dier geboren is (verondersteld wordt dat het effect van het bedrijf kan verschillen tussen jaren);

Effect geslacht $\quad=$ Ram of ooi;

Effect worpgrootte = Worpgrootte waarin lam geboren is (1,2,3 of 4 lammeren);

Effect geboortewicht = Lineair effect van gewicht van lam bij geboorte;

Genetische aanleg = Deel wat lam van zijn ouders geërfd heeft;

Permanent milieu = Invloed van gemeenschappelijk milieu dieren uit dezelfde worp

Rest term = Deel dat niet te verklaren is door de andere effecten;

De staartlengte is gemeten, de overige effecten (behalve de rest term) hebben verschillende groepen dieren gemeenschappelijk. Met behulp van een computerprogramma (in dit geval MIXBLUP) kunnen de effecten worden geschat, zodat de genetische aanleg gescheiden wordt van de andere invloeden op staartlengte. Geboortegewicht is in dit model meegenomen. Dit is gedaan omdat grotere schapen langere staarten hebben. Negeren van het effect van geboortegewicht op staartlengte in de fokwaardeschatting zou betekenen dat fokken op kortere staarten als gevolg heeft dat de schapen zelf ook kleiner worden. Door geboortegewicht mee te nemen in de fokwaardeschatting worden de staartlengtes gecorrigeerd voor geboortegewicht. Hierdoor leidt fokken op kortere staarten niet tot kleinere schapen. De fokwaardes in dit rapport gegeven zijn dus staartlengtes relatief ten opzichte van het gewicht. Een fokwaarde van - 1 betekent dat een schaap een genetische aanleg heeft voor een 1 centimeter kortere staart ten opzichte van de gemiddelde staartlengte voor schapen met hetzelfde gewicht.

De gekoppelde gegevens die de stamboeken beschikbaar gemaakt hebben voor dit onderzoek zijn de gegevens die dit jaar (2017) gebruikt worden voor de fokwaardeschatting. Het aantal aangeleverde geldige metingen is 2390 voor Clun Forest, 3871 voor Hampshire Down en 18221 records voor Suffolk.

Om te bepalen of de genetische aanleg voor staartlengte daadwerkelijk is gedaald is gekeken naar de gemiddelde fokwaarde van lammeren per geboortejaar. Daarnaast is gekeken naar de relatie tussen de fokwaarde en de gemeten staartlengtes. De gemeten staartlengte is gecorrigeerd voor geboortegewicht en omgerekend naar de staartlengte die verwacht mag worden voor een dier van 5 $\mathrm{kg}$. In de eerste plaats is gekeken naar uitbijters in de grafiek van fokwaarden tegen staartlengtes. Als de fokwaarde afwijkt van de gemeten lengte betekent dit dat de verwachte lengte op grond van verwanten anders is dan gemeten. Sterke afwijkingen kunnen een aanwijzing zijn van fouten in de metingen. In de tweede plaats is gekeken naar de bandbreedte van de fokwaarden ten opzichte van de gemeten waarden. Als voor een gegeven fokwaarde er een grote range is in werkelijke staartlengte, dan is de fokwaarde een onbetrouwbare voorspeller van de staartlengte. Als er minder informatie aanwezig is voor de staartlengte, bij een dier zelf en bij haar of zijn verwanten, dan komt de fokwaarde dichter bij 0 , het populatiegemiddelde, uit. Gevolg is daardoor ook dat de range in gemiddelde fokwaarden bij minder informatie ook veel kleiner is.

\subsubsection{Selectie intensiteit}

De effectiviteit van het fokprogramma hangt niet alleen af van hoe betrouwbaar de fokwaarden zijn maar ook van hoe sterk de daadwerkelijke selectie voor staartlengte is. Op twee momenten wordt er hierover een beslissing genomen. Het eerste en belangrijkste moment is als beslist wordt welke lammeren mogen blijven om later mee verder te fokken. Of en hoeveel een ram of ooi vervolgens ook daadwerkelijk voor de fokkerij gebruikt wordt is het tweede wat van invloed is op de gemiddelde staartlengte in de toekomst.

Worden lammeren voor de fokkerij aangehouden die gemiddeld een gunstiger fokwaarde hebben voor staartlengte dan de huidige populatie dan zal de staartlengte afnemen. Om dit te kunnen 
kwantificeren is naar de selectiedruk gekeken. Voor elk jaar is gekeken welke lammeren later vader of moeder zijn geworden. Vervolgens is voor ieder jaar gekeken of de lammeren die later ouder zijn geworden een andere gemiddelde fokwaarde hadden dan gemiddeld en is de selectie intensiteit uitgerekend. De gebruikte formule is:

Int. $=\left(L_{\text {selec }}-L_{\text {totaal }}\right) / \sigma(L)$

Waarbij

Int. = Selectie intensiteit

Lselec = Gemiddelde fokwaarde staartlengte van lammeren die later als ouder gebruikt zijn

Ltotaal = Gemiddelde fokwaarde staartlengte van alle lammeren die in dat jaar geboren zijn

$\sigma(\mathrm{L})=$ Standaard deviatie van de fokwaarde staartlengte van alle lammeren geboren in dat jaar

De intensiteit is een goede maat om te zien hoe hard er daadwerkelijk is geselecteerd op staartlengte bij geboorte. Bij een kenmerk waarop hard geselecteerd wordt zal de selectie intensiteit boven de 1 kunnen oplopen. De selectie intensiteit is ook vergeleken met de maximaal mogelijke selectie intensiteit. Die hangt af van het aantal selectiekandidaten dat beschikbaar is en het aantal dat elk jaar nodig is. Het aantal selectiekandidaten wordt bepaald door het aantal lammeren per worp en de uitval bij geboorte. Het aantal dat elk jaar nodig is hangt af van het vervangingspercentage en van inteeltbeperking. Bij kleine populaties wordt het aantal dekkingen per ram beperkt en moeten er daarom relatief meer rammen worden geselecteerd. De maximale selectie intensiteit is de ruimte die overblijft om te selecteren op kenmerken in het fokdoel, waarvan staartlengte er een is. Dit is berekend met een eenvoudige computersimulatie.

\subsubsection{Ingezette dieren}

Tenslotte is gekeken naar de individuele dieren die zijn ingezet in de fokkerij. In de eerste plaats is gekeken naar het generatie-interval. Het generatie-interval hangt af van het aantal jonge dieren dat ieder jaar wordt geselecteerd en van de leeftijd waarop de oudste dieren worden afgevoerd. Als er namelijk meer jonge dieren worden ingezet kan er beter geprofiteerd worden van hun gunstigere fokwaarde. Als de houders immers blijven vasthouden aan de oude dieren met lange staartlengtes duurt het langer voor geprofiteerd kan worden van een eventuele vooruitgang in fokwaarden. Het generatie-interval is berekend door de gemiddelde leeftijd van de vaders en de moeders te nemen.

Daarna is voor zowel de ooien als de rammen gekeken naar de fokwaarden van dieren die later zijn ingezet als fokdier. Dit is gebeurd voor dieren die zijn ingezet in 2016 en/of 2017. Van belang is of de dieren een gunstigere of ongunstigere fokwaarde hebben dan het gemiddelde van het ras, en of dit enkele dieren zijn of een groot deel van het ras. Omdat er veel minder rammen dan ooien nodig zijn kan de gemiddelde fokwaarde van ingezette rammen ook een stuk gunstiger zijn dan die van ingezette ooien. 


\section{Resultaten}

\subsection{Ervaringen in het veld}

Van elk ras zijn in augustus 5 fokkers gebeld. Er zijn twee fokkers geïnterviewd die inmiddels de schapen weggedaan hadden (verhuizing en leeftijd houder). De meeste gesprekken duurden tussen de 10 en 15 minuten met twee uitschieters van een half uur.

Het algemene beeld is dat er variatie tussen fokkers is. Wat ze gemeenschappelijk hadden is het enthousiasme voor de schapen. Elke fokker was op de hoogte van het fokprogramma voor kortere staarten en handelde daarnaar. Er was een fokker voor wie het geen prioriteit was en een paar deden mee omdat ze stamboekdieren wilden blijven houden: "je moet wel" is twee keer genoemd. Verder werd er gerefereerd aan de fokkerij op scrapie ongevoeligheid, waarbij ook succesvol een extra selectiecriterium aan de fokkerij is toegevoegd.

Elke geïnterviewde fokker meet bij de lammeren de staartlengte. Het aantal schapen per fokker dat in dat jaar gelamd had varieerde van 2 tot 13. Bij de Suffolk worden zowel ooi- als ramlammeren gecoupeerd, bij de Hampshire Down en Clun Forest alleen de ooilammeren. Er waren twee Clun Forest fokkers en een Suffolk fokker in de steekproef die niet coupeerden (Tabel 3.1). En er was een Hampshire Down fokker die per ongeluk het staartje van een geweldig mooi rammetje eraf gehaald had en dat kon daarom niet meer goedgekeurd worden voor de fokkerij.

Tabel 3.1 Samenvatting van de 15 interviews (5 per ras)

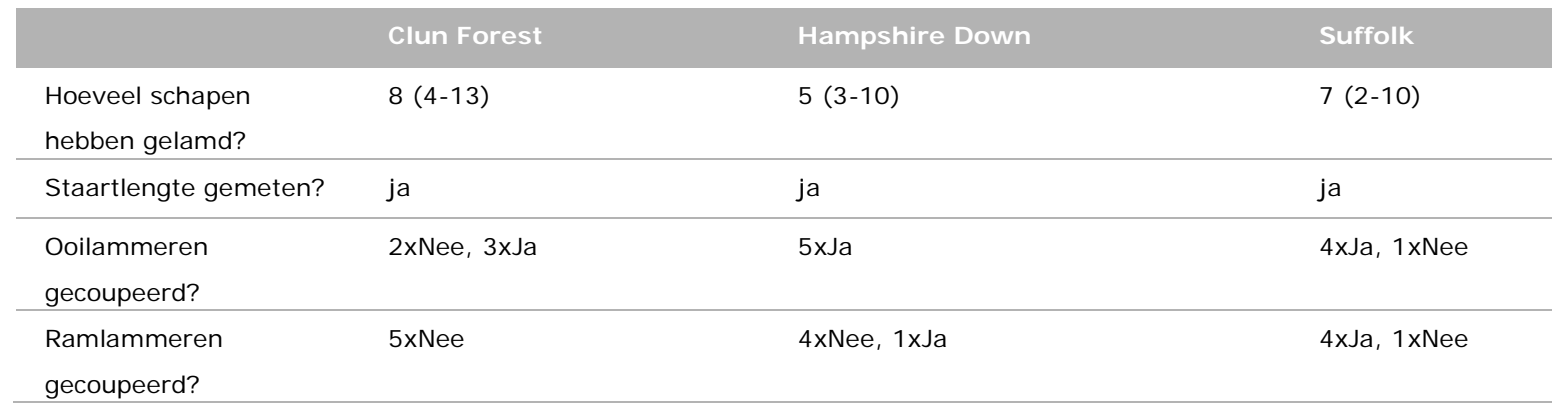

Hoe wordt een nieuwe ram gekozen? Niet voor iedereen was staartlengte een belangrijk selectiecriterium, voor de meerderheid wel. Naast staartindex / gunstige fokwaarde is meermalen genoemd: stamboekwaardig (raszuiver), karakter (makheid), exterieur / type / bouw, afstamming (moederlijnen / onverwant zijn), aflamgemak, snelle groei, mooi, goed bevruchten, van meerling, gezondheidsstatus. Een paar keer heeft een Suffolk fokker verwoord dat hij z'n goede ram van vorig jaar niet meer kon gebruiken omdat door de vooruitgang de grenzen van de fokwaarden aangescherpt waren.

Zijn de fokwaarden op tijd beschikbaar? Ja, zeiden de meesten. Voor Hampshire Down waren de fokwaarden niet centraal beschikbaar voor alle dieren. De fokkers die "andersom" werkten (dus eerst naar de ram kijken en dan naar bijbehorende fokwaarde) ervoeren dit probleem niet.

Is er vooruitgang te zien? Eigenlijk was iedereen van mening dat er wel wat gebeurd is, ook al gaat het langzaam. De meest aansprekende voorbeelden: vroeger hing de staart tot op de grond, nu tot op de hak. En: de oudere ooien hebben duidelijk langere staarten dan de jongere ooien. 


\section{Hoe wordt tegen het fokprogramma van kortere staarten aangekeken?}

\section{Clun Forest}

- Twee van de vijf geïnterviewde Clun Forest fokkers hadden hun ooien niet gecoupeerd. Daar zat ook een fokker bij die in begin wel gecoupeerd had, maar betere ervaringen heeft met niet couperen. Hij zit op goede kleigrond en heeft nogal eens last van vieze konten bij zijn schapen. Hij vindt dat schapen zonder staart meer last van maden hebben dan met staart. Voor een ander levert de volle wol wel problemen op. Een andere fokker heeft één jaar gecoupeerd omdat hij dacht dat het zo hoorde. Heeft weinig last van myasis. Gewoon schoon houden, zei hij. Hij vond couperen niet nodig en hoopte dat de ontheffing eraf gaat. Een schaap heeft een staart om vliegen weg te jagen.

- $\quad$ Een ander vond het noodzakelijk om te blijven couperen omdat de Clun Forest gevoelig is voor dunne ontlasting en de volle wol problemen geeft.

- $\quad$ Er was een fokker die het fokbeleid ter discussie stelde: verstandig paren van een lange staart ram met ooi met korte staart moet volgens hem ook kunnen. Hij had een mooi ramlam maar de staartindex was niet goed. Waarom mag deze niet ingezet worden op een ooi met korte staart was zijn vraag?

\section{Hampshire Down}

- $\quad$ Bij dit ras werd het vaakst gerefereerd aan de noodzaak van het couperen of het kaal houden (wol knippen of scheren) van de staart. Ook voor de rammen. Omdat het ras zo gevoelig voor maden is. Maar ook werd geconstateerd dat er veranderingen zijn in de staartlengte, bijvoorbeeld dat een dier zijn staart wel kon optillen bij het ontlasten en urineren.

- Genoemd werden waarnemingen dat het gedrag van de dieren anders wordt. Genoteerd: "de recentste ram tilde de staart aardig op" en "hij draagt z'n staart wel mooi"'.

- Ook is genoemd "we moesten ook wennen aan het gewijzigde uiterlijk."

- Genoteerd: "ons fokdoel is een staart van $13 \mathrm{~cm}$ ". En ook: "het is couperen met een doel, de gezondheid, niet voor schoonheid. Het is een verschrikking door die zware staart. Ook al kunnen maden ook in de nek voorkomen, het gebeurt toch vaak bij de staart".

\section{Suffolk}

- Suffolk fokkers gaven aan dat er flink aan de vooruitgang gewerkt wordt "dan heb je een goede ram, kun je hem het tweede jaar niet meer gebruiken omdat de normen aangescherpt zijn". Dat wordt geaccepteerd.

- $\quad$ Een biologisch-dynamische fokker zei "grote bewolde staarten zijn best lastig, maar niet onoverkomelijk".

- $\quad$ Bewustwording vond een fokker het belangrijkste winstpunt in dit traject. En hij was heel blij dat de fokkers de kans krijgen om kortere staarten te fokken. Het dierenleed is deels ondervangen door ander management gericht op schone achterwerken.

\section{Vermeldingswaardig}

Uit de interviews blijkt dat het allemaal liefhebbers zijn die genieten van de dieren: “Het is zo'n mooi dier. Je kijkt er met plezier naar" en "Je doet niet zomaar ooien weg. Het gaat om de uitstraling. Je fokt voor de mooiste."

\subsection{Technische evaluatie}

\subsubsection{Metingen aan staartlengte}

Bij alle drie de schapenrassen is de staartlengte van tweederde tot praktisch alle lammeren gemeten in de periode 2012 - 2017 (Tabel 3.2). Hierdoor is de hoeveelheid data nodig voor een betrouwbare fokwaardeschatting ruimschoots bereikt. Het aantal lammeren gemeten per jaar (figuur 3.1) tussen 2011 en 2016 lag voor de Clun Forest tussen de 250 en 300, voor de Hampshire Down tussen de 550 en 750. Voor de Suffolk nam het aantal gemeten lammeren af van ruim 1400 in 2009 tot 900 in 2017 , voornamelijk omdat er minder lammeren geboren zijn. Ook voor de Hampshire Down werden er minder lammeren geboren en gemeten in 2017. 
Tabel 3.2 Percentage lammeren gemeten in 2017 per ras

\begin{tabular}{lccc} 
Ras & Levend geboren, N & Gemeten, N & $\%$ gemeten \\
Clun Forest & 459 & 296 & $64 \%$ \\
\hline Hampshire Down & 664 & 412 & $62 \%$ \\
\hline Suffolk & 939 & 900 & $96 \%$ \\
\hline
\end{tabular}

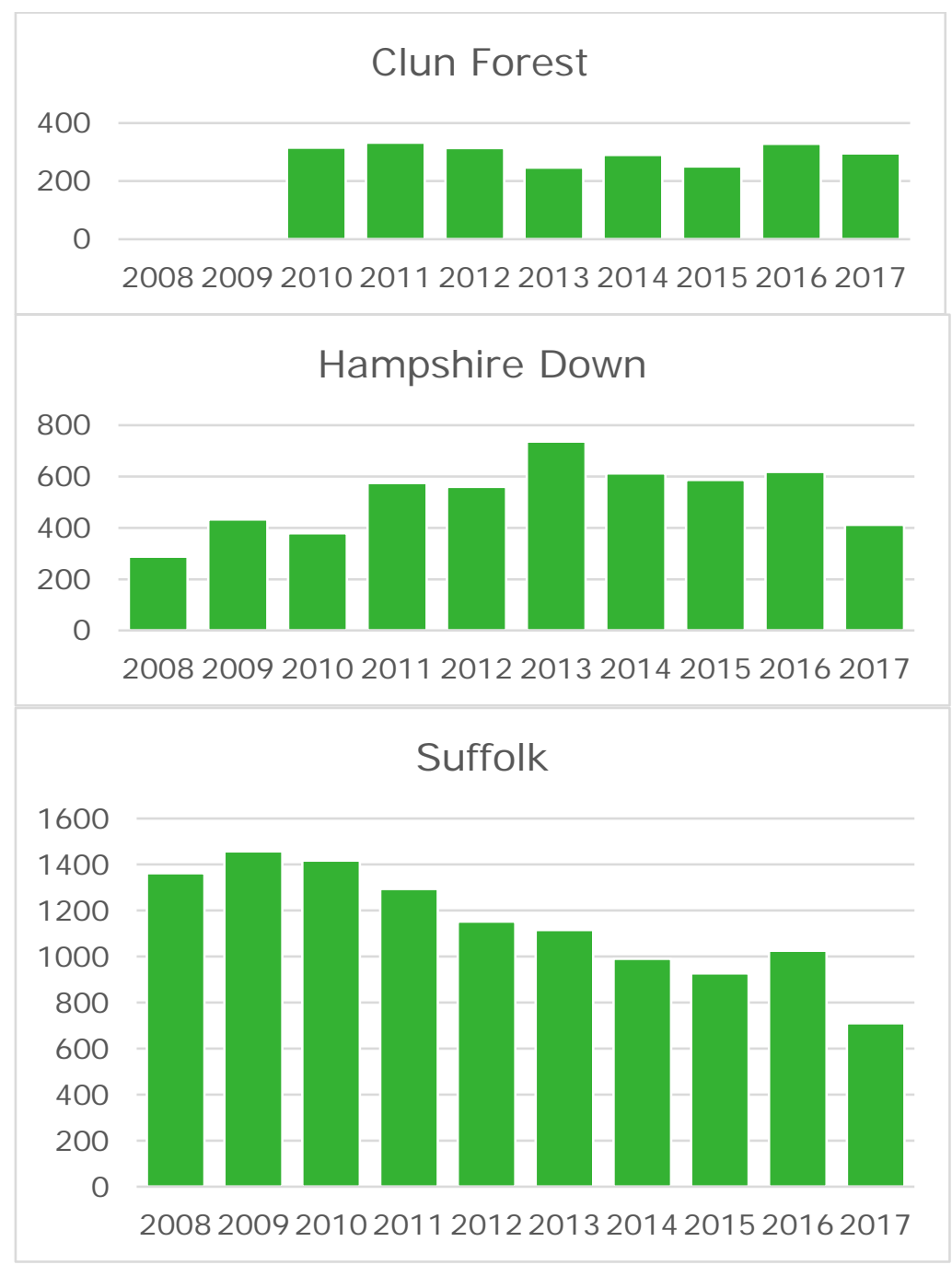

Figuur 3.1 Aantallen lammeren waarvan staartlengte is gemeten ten behoeve van de fokwaardeschatting per ras per jaar.

Bij grotere dieren zijn over het algemeen ook de staarten langer. Als de staartlengte tegen het geboortegewicht wordt uitgezet is deze relatie duidelijk te zien (Figuur 3.2). Bij de Clun Forest is de relatie zoals verwacht, maar bij de twee andere rassen zijn er uitzonderingen. Bij de Suffolk is er een gering aantal schapen die veel zwaarder zijn dan gemiddeld met relatief korte staarten terwijl er bij de Hampshire Down vrij veel schapen zijn met een lange staartlengte ten opzichte van het gewicht. Nadere inspectie laat zien dat deze van een paar bedrijven afkomstig zijn waar de opgegeven geboortegewichten en staartlengtes nauwelijks variëren. Daarnaast heeft het stamboek zelf gegevens van een aantal bedrijven uit de data verwijderd waarvan alle dieren dezelfde waarde hadden en daarom waarschijnlijk niet echt gemeten waren. 

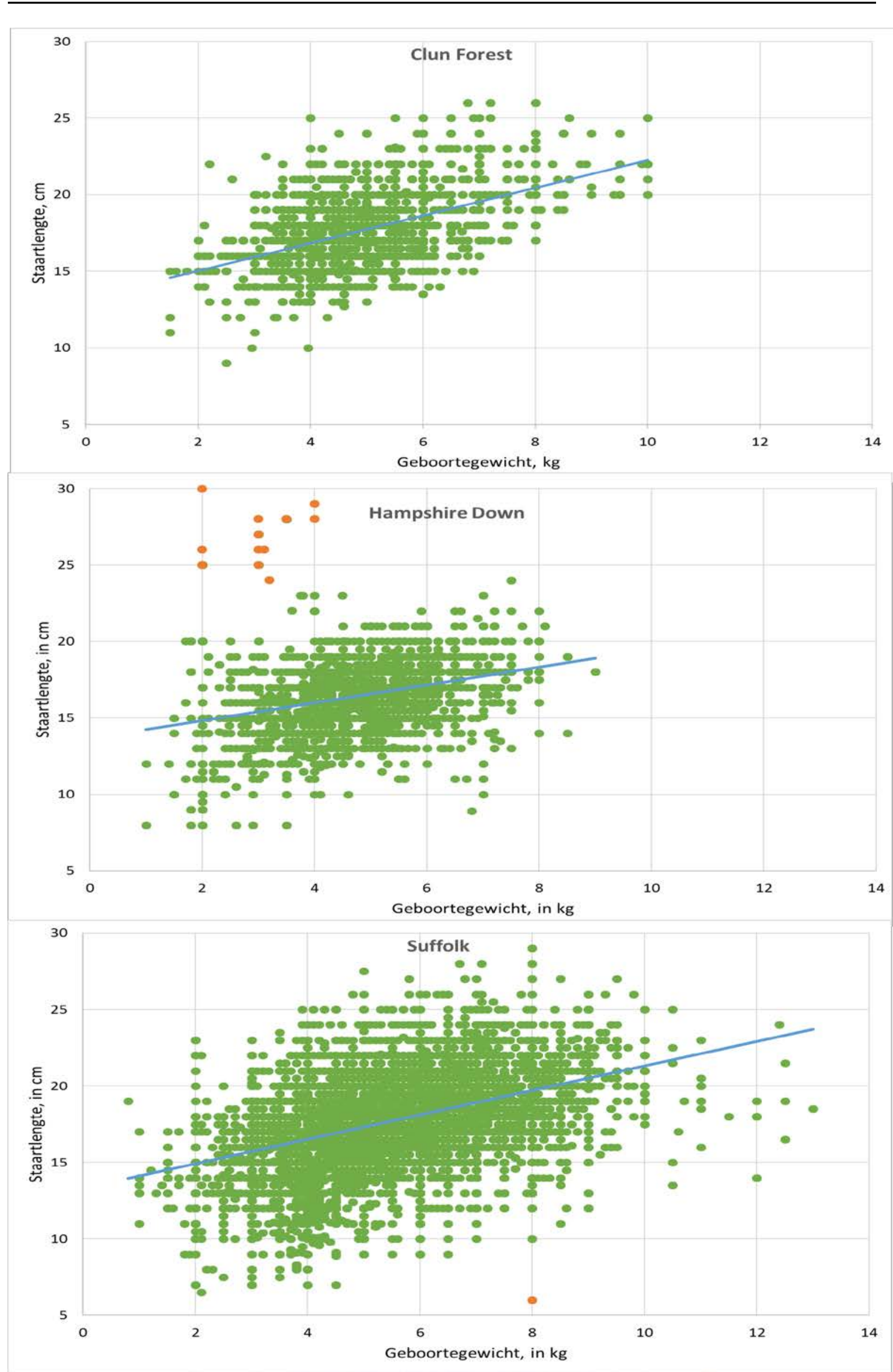

Figuur 3.2 Relatie gemeten staartlengte en geboortegewicht bij de drie schapenrassen. In oranje dieren met sterk afwijkende staartlengte. 


\subsubsection{Trends in staartlengte}

De fokwaarde voor staarlengte van lammeren is voor zowel de Clun Forest als de Suffolk afgenomen (Figuur 3.3). De afname bij de Suffolk is sinds 2008 constant, bij de Clun Forest begon de afname in 2011 en is sinds 2013 constant. Bij de Hamphire Down is de fokwaarde niet gedaald.

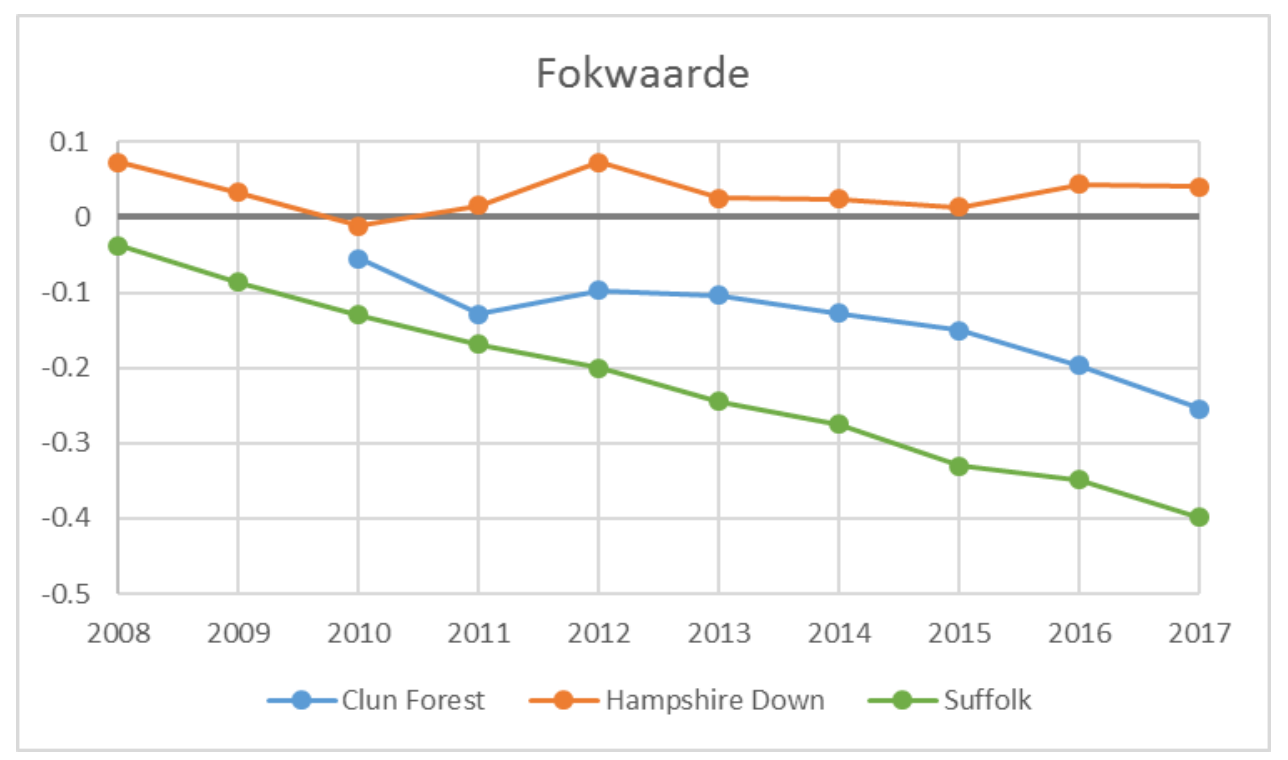

Figuur 3.3 Gemiddelde fokwaarde voor staartlengte per geboortejaar per schapenras.

De werkelijke staartlengte is bij de Clun Forest sinds 2010 met $2 \mathrm{~cm}$ afgenomen, bij de Suffolk met $1 \frac{1 / 2}{c m}$ sinds 2008, terwijl de staartlengte bij de Hampshire Down met ongeveer $1 / 4 \mathrm{~cm}$ is toegenomen (Figuur 3.4). Bij alle drie de schapenrassen is de gemiddelde staartlengte nu ongeveer $16^{1 / 2} \mathrm{~cm}$. Wordt de trend doorgetrokken naar de toekomst dan wordt een lengte van $10 \mathrm{~cm}$ bereikt bij de Clun Forest omstreeks 2040 en bij de Suffolk omstreeks 2060.

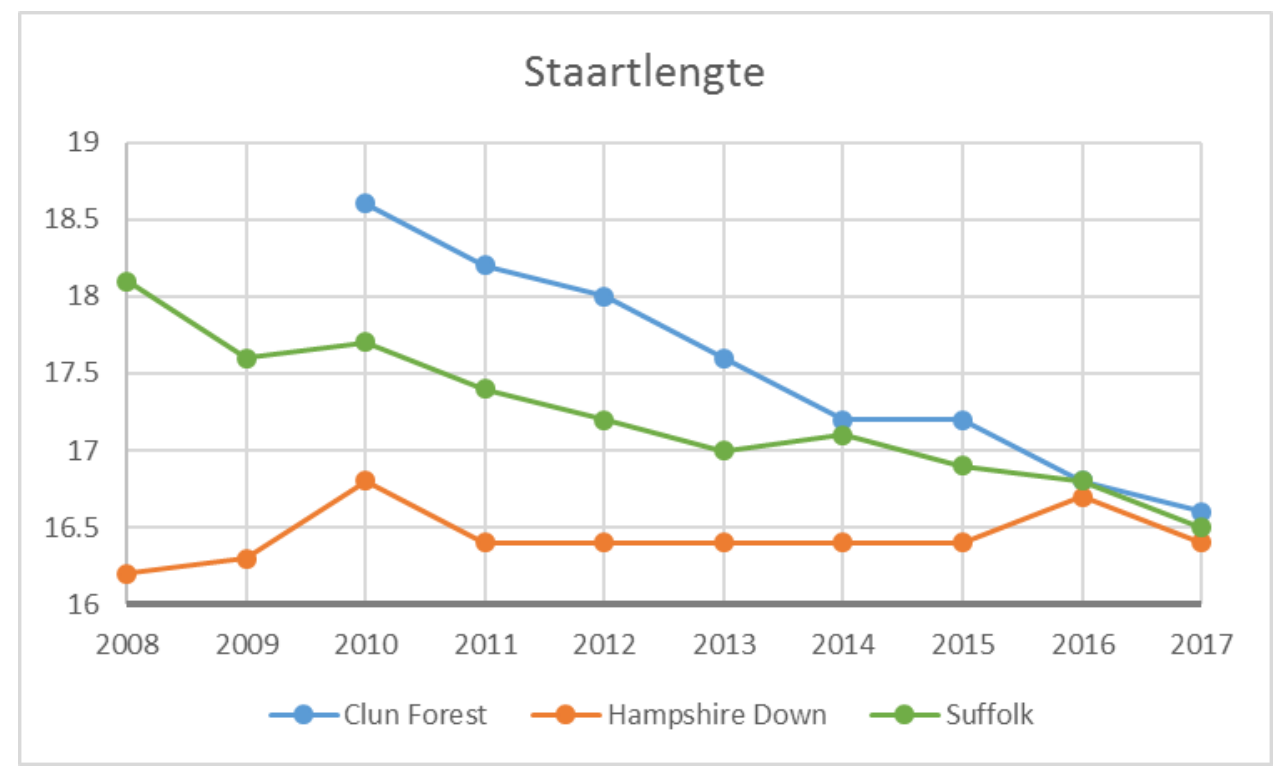

Figuur 3.4 Gemiddelde staartlengte per geboortejaar per schapenras.

De relatie tussen de fokwaarde en de staartlengte verschilt tussen de rassen (Figuur 3.5). Bij de Hampshire Down zijn er een aantal dieren met een lange gemeten staart, met een relatief korte fokwaarde voor staartlengte. Bovendien is voor een gegeven fokwaarde de variatie in staartlengte groot, met andere woorden is de voorspellende waarde van de fokwaarde voor de werkelijke staartlengte niet erg groot. Bij een fokwaarde van $+0.5 \mathrm{~cm}$ ligt de gemeten staartlengte tussen de 15 en $20 \mathrm{~cm}$ afgezien van uitschieters van $8 \mathrm{~cm}$ en $28 \mathrm{~cm}$, bij een fokwaarde van -0.5 tussen de 12 en 17 
$\mathrm{cm}$. Bij de Clun Forest is de relatie tussen fokwaarde en gemeten staartlengte veel nauwer en zijn er geen afwijkende waarden. Bij een fokwaarde van $+0.5 \mathrm{~cm}$ ligt de gemeten staartlengte tussen de 20 en $25 \mathrm{~cm}$, bij een fokwaarde van - 0.5 tussen de 15 en $20 \mathrm{~cm}$. Bij de Suffolk is het onderscheidend vermogen van de fokwaarde nog groter. Bij een fokwaarde van 120 (fokwaarde bij de Suffolk is op een andere schaal uitgedrukt, en 120 wil zeggen twee standaard deviaties in gunstige richting, d.w.z. kortere staartlengte) is de gemeten staartlengte tussen de 13 en $15 \mathrm{~cm}$ bij een fokwaarde van 80 tussen de 20 en $23 \mathrm{~cm}$. De voorspellende waarde van de fokwaarde voor de werkelijke staartlengte is dus groter bij de Clun Forest en vooral bij de Suffolk in vergelijking met de Hampshire Down.

Wanneer bij Hampshire Down de bedrijven met een structureel onwaarschijnlijke relatie tussen geboortegewicht en staartlengte worden weggelaten, dan verandert een klein aantal fokwaarden zeer sterk, maar voor de overige dieren is de rangorde min of meer gelijk (correlatie is 0,996 ). 


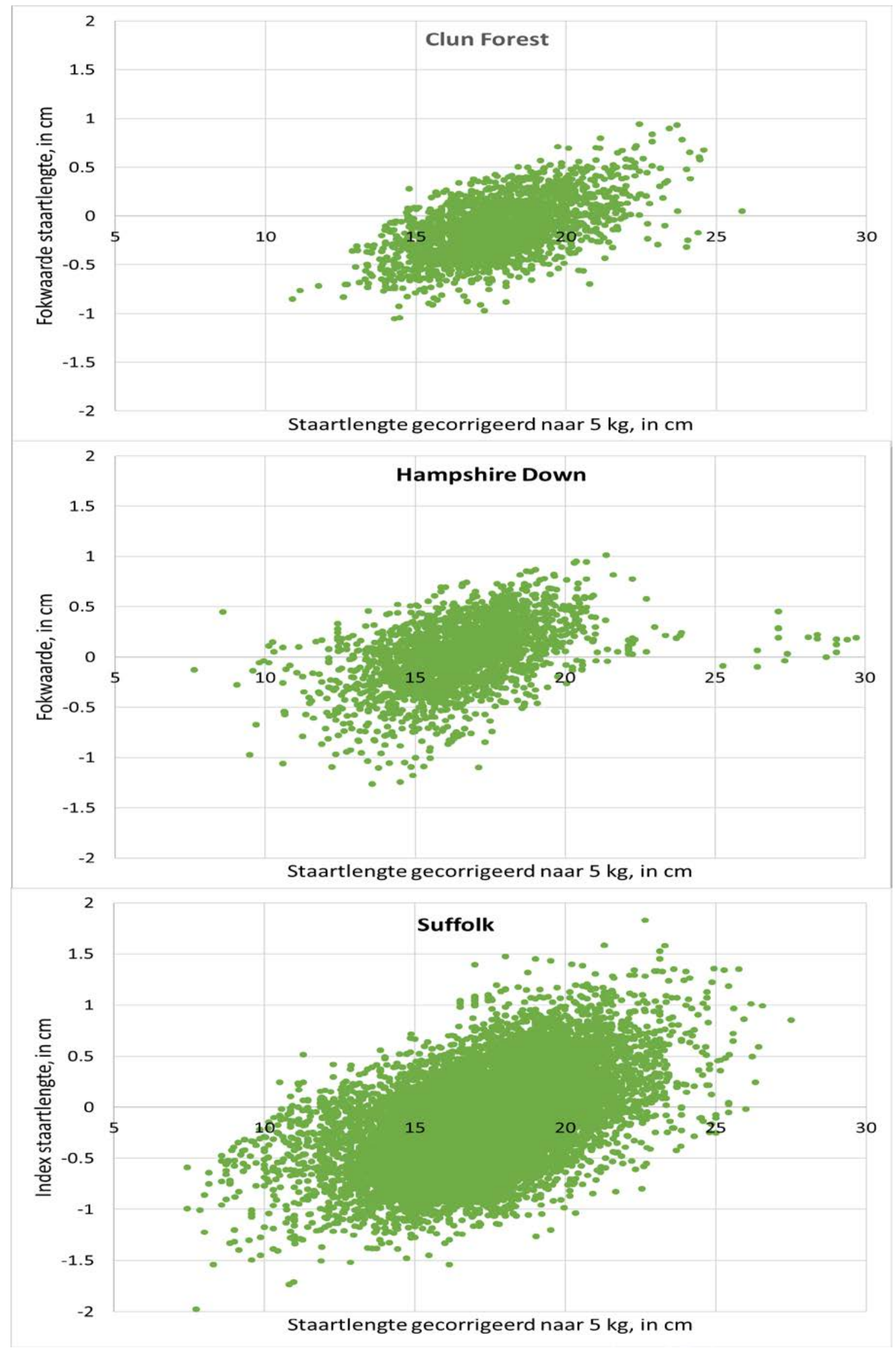

Figuur 3.5 Fokwaarde staartlengte vs. werkelijke staartlengte gecorrigeerd naar $5 \mathrm{~kg}$. 


\section{Selectie intensiteit}

De selectie intensiteit uitgedrukt als het verschil in staartlengte tussen lammeren geselecteerd voor de fokkerij en lammeren niet geselecteerd was onveranderd gunstig voor de Suffolk rammen tussen 2012 en 2017 (Figuur 3.6). Voor de Clun Forest was dit het geval vanaf 2014. Voor de Hampshire Down zijn juist rammen geselecteerd met een licht ongunstige fokwaarde tussen 2012 en 2015 en licht gunstig in 2017. Voor ooien was de fokwaarde van geselecteerde dieren vrijwel gelijk aan niet geselecteerde dieren. Omdat er nog maar weinig ooien die zijn geboren in 2016 al in de fokkerij zijn ingezet kan de selectie intensiteit gevonden voor dieren geboren in dat jaar nog flink veranderen.
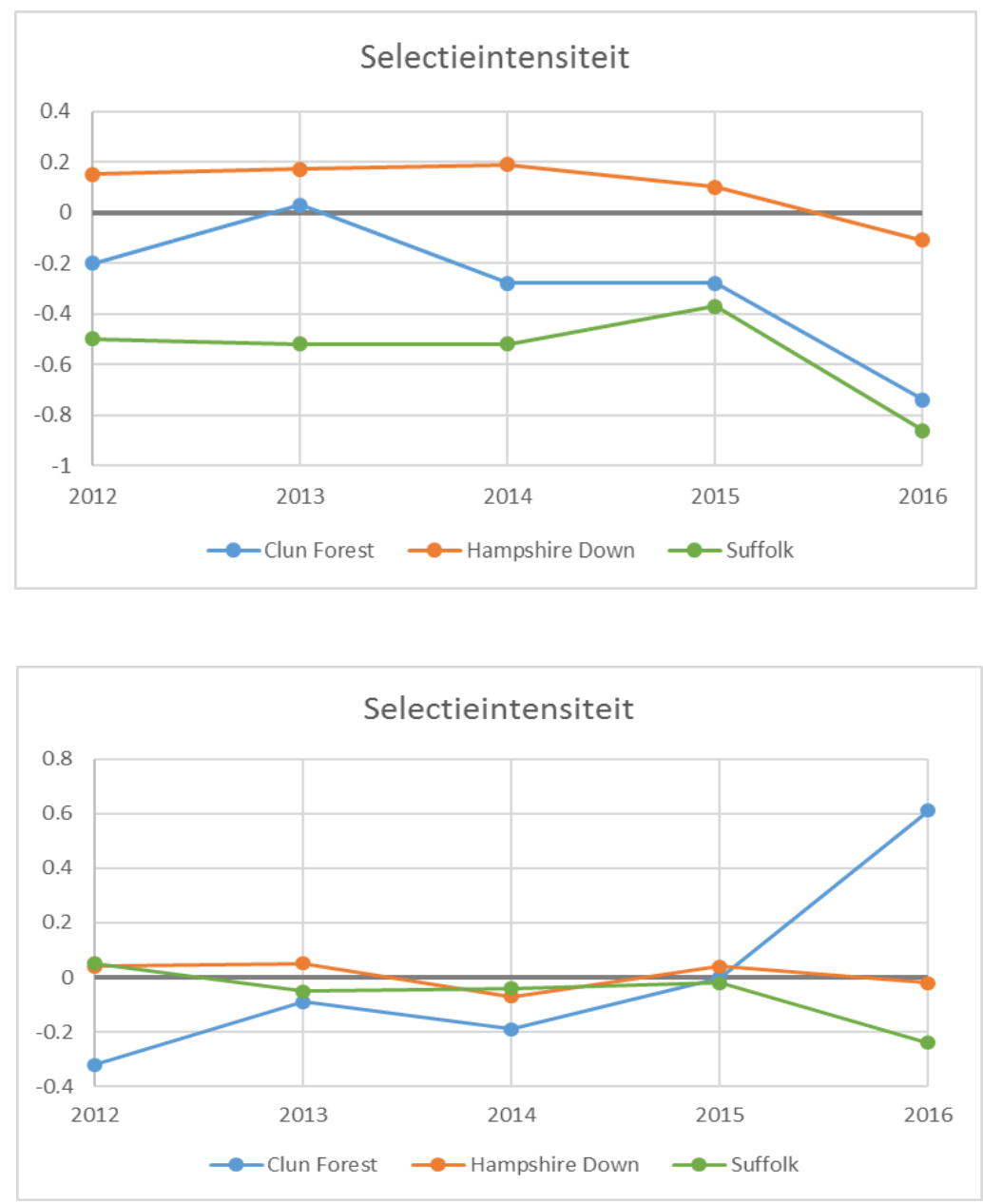

Figuur 3.6 Selectie intensiteit per geboortejaar voor rammen (boven) en ooien (onder): verschil tussen gemiddelde staartlengte geselecteerde en niet-geselecteerde dieren van dezelfde sekse en geboortejaar uitgedrukt in standaarddeviaties.

Kijken we naar de gerealiseerde selectie intensiteit dan zien we dat die bij de Hampshire Down $0 \%$ van de theoretisch maximaal haalbare selectie intensiteit (Tabel 3.3). Bij de Clun Forest is deze 17,4 $\%$ en bij de Suffolk 33,8 \%. Dit laatste percentage is aanzienlijk, aangezien er ook altijd op andere kenmerken dan staartlengte geselecteerd moet worden, zoals exterieur, gezondheid, vruchtbaarheid en afstamming.

Bij Hampshire Down lijkt er een tweedeling te zijn van fokkers die wel serieus selecteren op kortere staarten en fokkers die dit niet doen. De stamboekvertegenwoordiging van Hampshire Down heeft gevraagd naar de consequenties indien de selectie voor kortere staarten beperkt wordt tot de fokkers die serieus selecteren. De andere fokkers die wel gebruik willen maken van de ontheffing zouden dan, ofwel alleen rammen van deze bedrijven mogen gebruiken, ofwel moeten stoppen met couperen. Bij deze optie wordt de fokpopulatie beperkt tot 150 ooien. De maximale selectie intensiteit is hetzelfde als voor 450 ooien, maar de kans dat er door toeval geen gewenste respons is, is aanzienlijk groter (spreiding genetische drift neemt toe van 0,12 naar 0,20). 
Tabel 3.3 Selectie intensiteit voor de periode 2012-2017. Maximale selectie intensiteit is de intensiteit die gerealiseerd zou kunnen worden als alleen op staartlengte zou worden gefokt gegeven vruchtbaarheid, vervanging en inteeltbeperking

\begin{tabular}{llll} 
& Clun Forest & \multicolumn{2}{c}{ Hampshire } \\
Gemiddelde selectie intensiteit/jaar & & Down \\
\hline Maximale selectie intensiteit/jaar & 0,047 & $-0,006$ & 0,125 \\
\hline Gerealiseerde selectiedruk op staartlengte & 0,27 & 0,25 & 0,37 \\
\hline
\end{tabular}

\subsubsection{Ingezette dieren}

Door jongere dieren te gebruiken voor de fokkerij kan er meer geprofiteerd worden van de genetische vooruitgang. Bij de Clun Forest is dit ook daadwerkelijk gebeurt (Figuur 3.7). Bij de Suffolk was het generatie-interval al laag, en is het iets gestegen in de afgelopen 5 jaar. Bij de Hampshire Down is het generatie-interval onveranderd hoog.

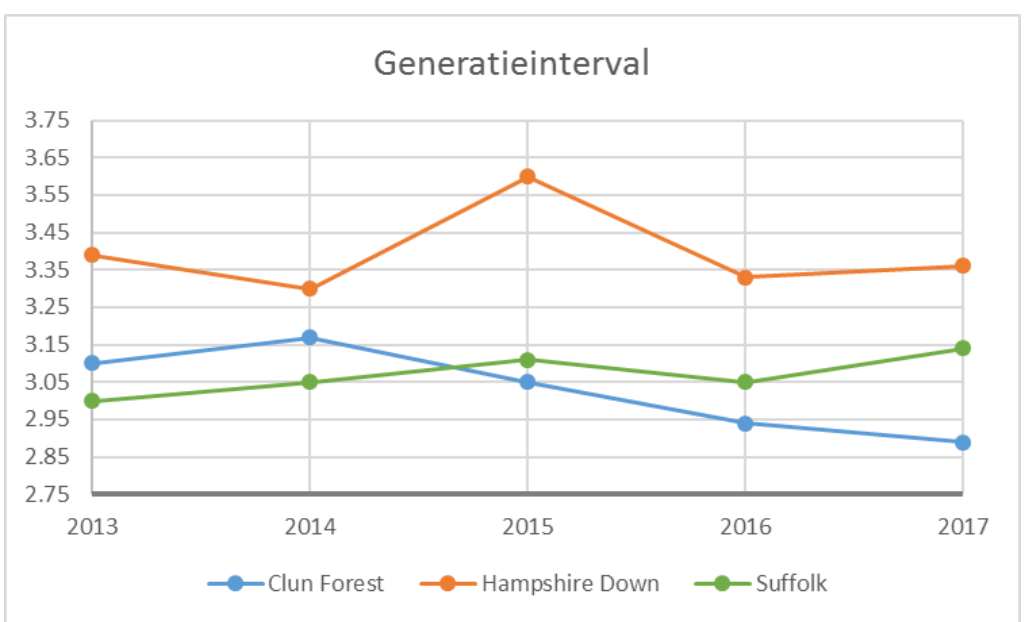

Figuur 3.7 Generatie-interval, gemiddelde leeftijd ouders bij geboorte van lammeren.

De rammen die ingezet zijn voor de fokkerij hebben een fokwaarde bij de Hampshire Down die varieert van -0.8 tot +0.8 (Figuur 3.8). Ongeveer de helft van de ingezette rammen heeft een fokwaarde die ongunstiger ligt dan het gemiddelde van het ras. Bij de Clun Forest varieert de fokwaarde van -0.9 tot 0.5 , en zijn slechts enkele rammen met een ongunstige (positieve) fokwaarde ingezet. Bij de Suffolk varieert de fokwaarde van ingezette rammen van -1.1 tot +0.1 . Ondanks dat de gemiddelde fokwaarde bij dit ras al gunstiger ligt zijn toch nog redelijk wat ongunstige rammen ingezet.

\section{Hampshire Down}

\section{Clun Forest}

Suffolk
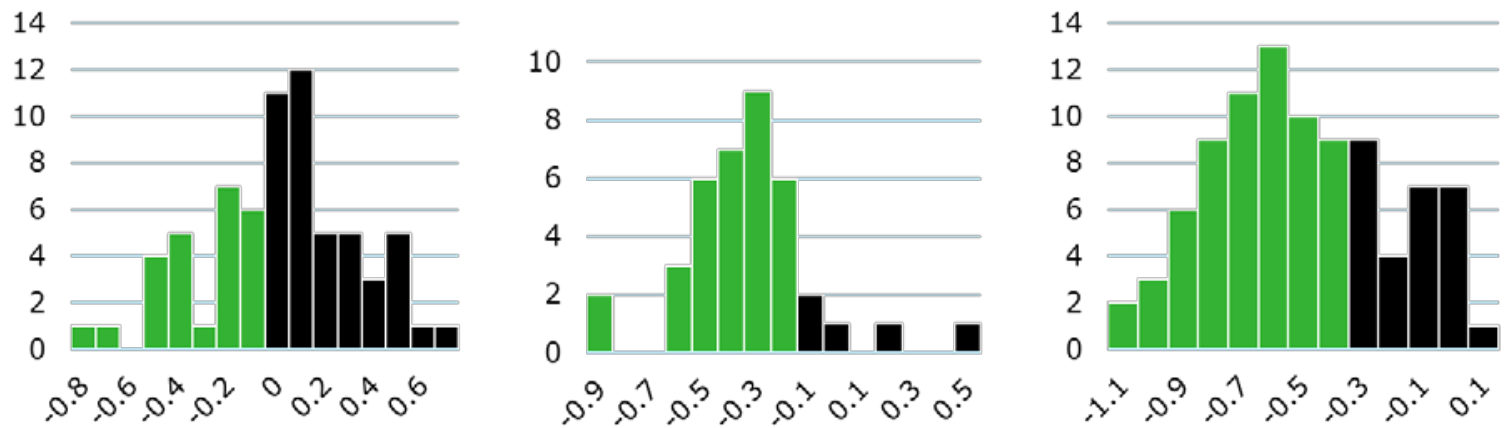

Figuur 3.8 Fokwaarde ingezette rammen in 2016. In groen rammen met een gunstiger fokwaarde dan gemiddeld in de populatie van 2016, in zwart rammen met een ongunstiger fokwaarde dan gemiddeld. 
De selectie bij ooien heeft minder invloed op het rasgemiddelde dan bij rammen, en is dan ook minder sterk geweest. Toch is duidelijk dat ook bij de ooien minder geselecteerd is in de Hampshire Down dan bij de andere twee rassen (Figuur 3.9). Bij alle drie de rassen wordt een aantal ooien ingezet met een relatief ongunstige fokwaarde.

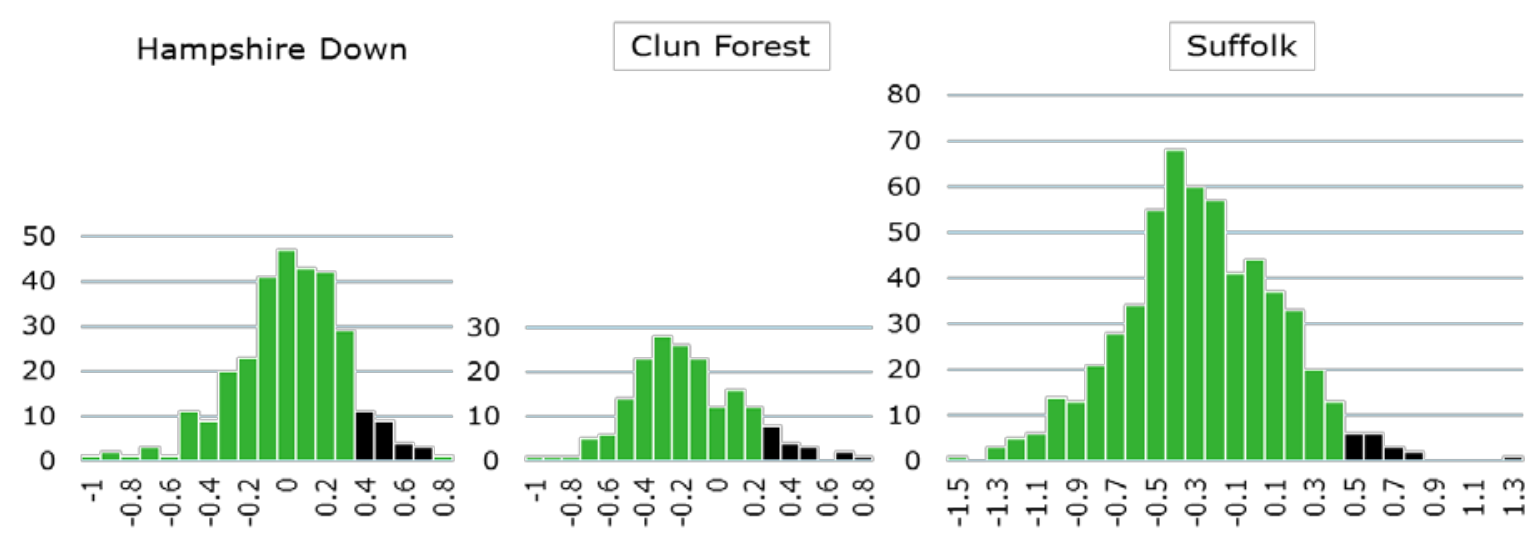

Figuur 3.9 Fokwaarde ingezette ooien in 2016. In groen ooien met een gunstige fokwaarde, in zwart ooien met een veel ongunstiger fokwaarde dan gemiddeld per ras. 


\section{$4 \quad$ Discussie}

Het fokprogramma is bij alle drie de rassen van start gegaan, en alle fokkers zijn van het programma op de hoogte. Binnen de rassen is het fokprogramma echter wisselend opgepakt. Hieronder worden eerst de resultaten per ras besproken, waarna bediscussieerd wordt hoever de programma's vorderen richting het gewenste einddoel.

\subsection{Clun Forest}

Samenvattend voor de Clun Forest:

- Genetische trend gaat de goede kant op

- Fenotypische trend verandert sterker dan verwacht op basis van de genetische trend

- Aantal gemeten dieren is constant over de jaren heen

- Selectie intensiteit rammen is goed

- Selectie intensiteit ooien is ook goed, maar eerste selectie 2016 is slechter dan gemiddeld

- $21 \%$ van de selectieruimte is benut voor staartlengte. Dit percentage zou nog iets hoger kunnen

- Enkele fokdieren met een ongunstige fokwaarde en onterecht geselecteerde dieren verminderen de genetische vooruitgang. De meeste dieren hiervan zijn importrammen uit Groot-Brittannië. Deze hebben een sterk ongunstig effect op de populatie. Metingen aan nakomelingen maken duidelijk dat ze niet geschikt zijn om de populatie qua staartlengte te verbeteren (wel qua genetische diversiteit).

\subsection{Hampshire Down}

Bij de Hampshire Down vallen de volgende punten op:

- $\quad \mathrm{Er}$ is geen genetische trend

- $\quad$ r is geen fenotypische trend

- Aantal gemeten dieren was constant over de jaren heen, maar is recent gedaald

- Fokwaarden hebben geen goede relatie met werkelijke staartlengte

- Selectie intensiteit van rammen en ooien is nul

Over het geheel genomen is het fokprogramma dus niet succesvol. Dat wil niet zeggen dat er in het geheel geen vooruitgang is. Een deel van de fokkers is namelijk wel succesvol: 22 van de 66 fokkers zijn in gemiddelde fokwaarde ruim $0,2 \mathrm{~cm}$ de goede kant op gegaan sinds 2012. De problemen zijn veroorzaakt door twee zaken:

1. De informatie is niet van goede kwaliteit.

Door onbetrouwbare metingen zijn de berekende fokwaarden minder betrouwbaar. Daarnaast waren voor de ramlammeren van 2017 geen fokwaarden beschikbaar (zie ook telefonische enquête). Door technische problemen bij de dienstverlener zijn dieren noodgedwongen ingezet zonder dat de gegevens bekend zijn.

2. Informatie wordt niet gebruikt bij fokbeslissingen (slechts door een derde van de fokkers wel). Deels komt dit doordat de fokwaarden niet snel beschikbaar zijn, maar deels ook doordat kortere staarten niet door alle fokkers als prioriteit wordt gezien.

De foktechnische commissie van de Hampshire Down geeft aan dat in 2013, bij de start van het coupeerverbod voor de rammen bij hun vereniging een paar fokkers zijn gestopt en in dat jaar zijn nog massaal oude gecoupeerde rammen ingezet, vanaf dat moment gaat lengte wel naar beneden. De beleving is dat bij lammerinspectie zichtbaar is dat de staarten afgelopen jaren wel korter geworden zijn (en dat is ook wat fokkers in de telefonische interviews aangeven). 


\subsection{Suffolk}

Samenvattend voor de Suffolk kan gesteld worden:

- Genetische trend gaat de goede kant op

- Fenotypische trend gaat de goede kant op

- Selectie intensiteit rammen is goed

- Selectie intensiteit ooien ook goed

- $30 \%$ van de selectieruimte is benut voor staartlengte. Dit is goed en zou nog iets hoger kunnen

- Enkele fokdieren met een ongunstige fokwaarde en onterecht geselecteerde dieren verminderen de genetische verandering per generatie

Het Suffolk Stamboek Nederland onderschrijft dat de resultaten goed zijn, en dat het einddoel een kortere staart fokken zodat het couperen achterwege kan blijven onverminderd blijft. De verwachting is dat ze in 2027 een eind op weg zullen zijn, maar of de staarten dan daadwerkelijk opgetild kunnen worden is vooralsnog onzeker. De adviezen van de WUR worden meegenomen in de ontwikkeling van het toekomstig fokbeleid en het SSN bestuur legt aan haar leden een besluit voor om de selectie intensiteit te verhogen. Daarnaast zal de mogelijkheid onderzocht worden om een fokwaarde wormresistentie in te voeren.

\subsection{Het gewenste einddoel}

Het project is gestart met de doelstelling om de gemiddelde staartlengte te halveren in 20 jaar en zo couperen overbodig te maken. Na 10 jaar zien we dat dit niet in die periode haalbaar is, zelfs niet door een stamboek dat het fokprogramma vanaf het begin redelijk goed heeft geïmplementeerd.

De relatie tussen gevoeligheid voor myasis en staartlengte is niet een op een: met extra zorg om de staarten schoon te houden kan myasis ook worden voorkomen. Toch is dit geen reden om dan maar te stoppen met deze fokprogramma's, want schapen van deze rassen zouden dan afhankelijk blijven van een bovengemiddeld niveau van verzorging.

De vraag is dus bij welke staartlengte een normale verzorging myasis afdoende voorkomt. Als die lengte is bereikt kan de ontheffing van het coupeerverbod ingetrokken worden.

\subsection{Aanbevelingen om programma aan te scherpen}

Het fokprogramma voor zowel de Suffolk en Clun Forest is goed onderweg, het fokprogramma voor de Hampshire Down moet nog sterk verbeteren. De volgende aanbevelingen kunnen helpen het fokprogramma verder te verbeteren. Een deel van de aanbevelingen is bij sommige stamboeken al doorgevoerd, maar is voor alle drie de stamboeken aan te bevelen.

- Voeg tussentijdse rapportage toe.

De fokprogramma's worden nu eens in de 5 jaar uitgebreid geëvalueerd. Naast deze uitgebreide evaluatie kan een jaarlijkse korte rapportage door de stamboeken helpen om de voortgang te bewaken. In zo'n rapportage moet worden opgenomen:

o Aantal levend geboren lammeren en aantal gemeten

- Percentage geselecteerde rammen en hun gemiddelde fokwaarde

o Percentage geselecteerde ooien en hun gemiddelde fokwaarde

Dit geeft informatie over de meetbereidheid en de selectie.

- Actieve promotie van het project in eigen geledingen.

Met name bij de Hampshire Down kan dit verbeterd worden. Voor zover nog niet ingevoerd kan overwogen worden:

o Informatie op de website

o Aandacht op keuringen

o Rapportage en oproep op ALV

o Meet- en selectieprotocol beschikbaar, via website 
o Infopakket met meetlat voor alle (nieuwe) leden

- Centrale lijst van rammen met status (opfokram, dekram) en fokwaarde beschikbaar maken.

Door middel van een eenvoudige code (bijvoorbeeld groen, oranje en rood) kunnen

rammen worden aanbevolen of afgeraden voor gebruik. Aanbevolen wordt om het gebruik van de $40 \%$ rammen met de meest ongunstige fokwaarde (= langste staarten) af te raden (code rood), het gebruik van de $40 \%$ rammen met de gunstigste fokwaarde aan te raden (code groen) en de $20 \%$ tussenliggende rammen liever niet te gebruiken (code oranje). Met deze percentages zijn voldoende rammen beschikbaar voor de fokkerij, en blijft de gewenste selectie intensiteit gehandhaafd. Het verdient geen aanbeveling om een ram met een ongunstige fokwaarde toch in te zetten, ook al paar je deze met ooien met een gunstige fokwaarde. Het probleem blijft namelijk dat de ram zijn ongunstige genetische aanleg verspreid in de populatie. Weliswaar komt dit bij zijn directe nakomelingen niet tot uiting door de gunstige genetische aanleg van de ooien, maar in volgende generaties is dit niet meer het geval.

- Zorgen dat leverancier van fokwaarden tijdig volledige lijsten met fokwaarde van beschikbare dieren levert.

Tenslotte zal bij de Hampshire Down een actief beleid moeten worden opgezet om te voorkomen dat leden verkeerde metingen in sturen. Bij vermoeden van incorrecte metingen dient contact te worden opgenomen met de fokker om een oplossing te vinden. 


\section{$5 \quad$ Conclusie}

Bij alle drie de rassen is de fokwaardeschatting goed opgezet. Het fokprogramma heeft in de Hampshire Down echter nog niets opgeleverd. Deels komt dit doordat de berekende fokwaarden minder betrouwbaar zijn door onbetrouwbare metingen van de staartlengtes, maar vooral omdat er bij het selecteren van fokdieren geen rekening wordt gehouden met de fokwaarde voor staartlengte. Het fokprogramma in de Clun Forest is sterk verbeterd ten opzichte van 2012, en de staartlengte vermindert nu ook daadwerkelijk. Het fokprogramma in de Suffolk is onveranderd goed sinds 2008, en de staartlengte vermindert nog steeds.

Het fokprogramma in de Hampshire Down moet sterk verbeterd worden wil de staartlengte daadwerkelijk naar beneden gaan. Bij de andere twee rassen is een relatief groot gedeelte van de selectieruimte gebruikt voor het verkorten van de staarten en zijn nog slechts lichte verbeteringen mogelijk.

Het gewenste einddoel om in 20 jaar de gemiddelde staartlengte te halveren en zo couperen overbodig te maken zal niet gehaald worden. De vraag is bij welke staartlengte een normale verzorging myasis afdoende voorkomt. 


\section{Literatuur}

Pijpers, A., A. Stegeman, H. Hopster en P. Vellema. 2006. Het is in de Nederlandse situatie mogelijk om met goed management verantwoord schapen te houden zonder het couperen van staarten. In: library.wur.nl/ebooks/minlnv/rapporten/1883153.pdf

Windig J.J. 2007. Verwantschap en mogelijkheden fokprogramma van Engelse schapenrassen in relatie tot couperen van staarten. ASG rapport 07/84

Windig J.J., D.I. Bohte-Wilhelmus en A.H. Hoving-Bolink. 2009. Stand van zaken fokprogramma voor kortere staarten bij drie schapenrassen met een ontheffing op het coupeerverbod. ASG rapport 270

Windig J.J ., J. ten Napel en R. Hoving-Bolink. 2012. Stand van zaken fokprogramma voor kortere staarten bij drie schapenrassen met een uitzondering op het coupeerverbod. Livestock Research Wageningen UR rapport 656. 


\section{Bijlage 1 Belscript random steekproef onder fokkers}

Goedemorgen/middag/avond,

U spreekt met Rita Hoving van Wageningen Universiteit en Research. Ik bel omdat ik degene die "ras" fokt graag een paar vragen wil stellen. Komt het op dit moment gelegen of kan ik beter een tijdstip afspreken om opnieuw te bellen?

Het gaat om het volgende. De Suffolk, Clun Forest en Hampshire Down hebben een tijdelijke coupeer ontheffing gekregen. Wageningen Livestock Research evalueert om de 5 jaar de voortgang en dit jaar wil het ministerie ook graag dat we een steekproef van fokkers naar hun ervaringen vragen. Wij hebben uit alle stamboekleden 5 telefoonnummers gekozen en u bent er een van. We behandelen uw antwoorden vertrouwelijk. In ons rapport zal niet te zien zijn wie wat gezegd heeft. Mag ik u nu de vragen stellen of liever op een ander tijdstip?

1. Hoeveel schapen hebben dit jaar gelamd?

2. Heeft u de staartlengtes van de lammeren gemeten en doorgegeven?

3. Heeft $u$ de ooilammeren gecoupeerd?

4. En de ramlammeren?

5. Moet $\mathrm{u}$ voor komend dekseizoen een nieuwe ram kiezen/aanschaffen?

6. Hoe gaat $u$ die kiezen (of hoe hebt $u$ de vorige gekozen)?

7. Vind $u$ het belangrijk om te fokken naar kortere staarten?

8. Zijn er fokwaarden voor staartlengte beschikbaar?

9. Houdt $u$ rekening met de fokwaarde voor staartlengte?

10. Zijn de fokwaarden op tijd beschikbaar, als u wilt selecteren?

11. Zijn op uw bedrijf afgelopen 10 jaar de staartlengtes veranderd? Kunt $u$ het met getallen onderbouwen?

12. Wordt er binnen de vereniging over gesproken? Op welke manier?

13. Wat merkt u van het fokprogramma voor kortere staarten?

14. Dank.

15. Ik heb geen vragen meer. Kort samengevat neem ik de volgende punten mee uit ons gesprek. Wilt u nog iets vragen of meegeven? 


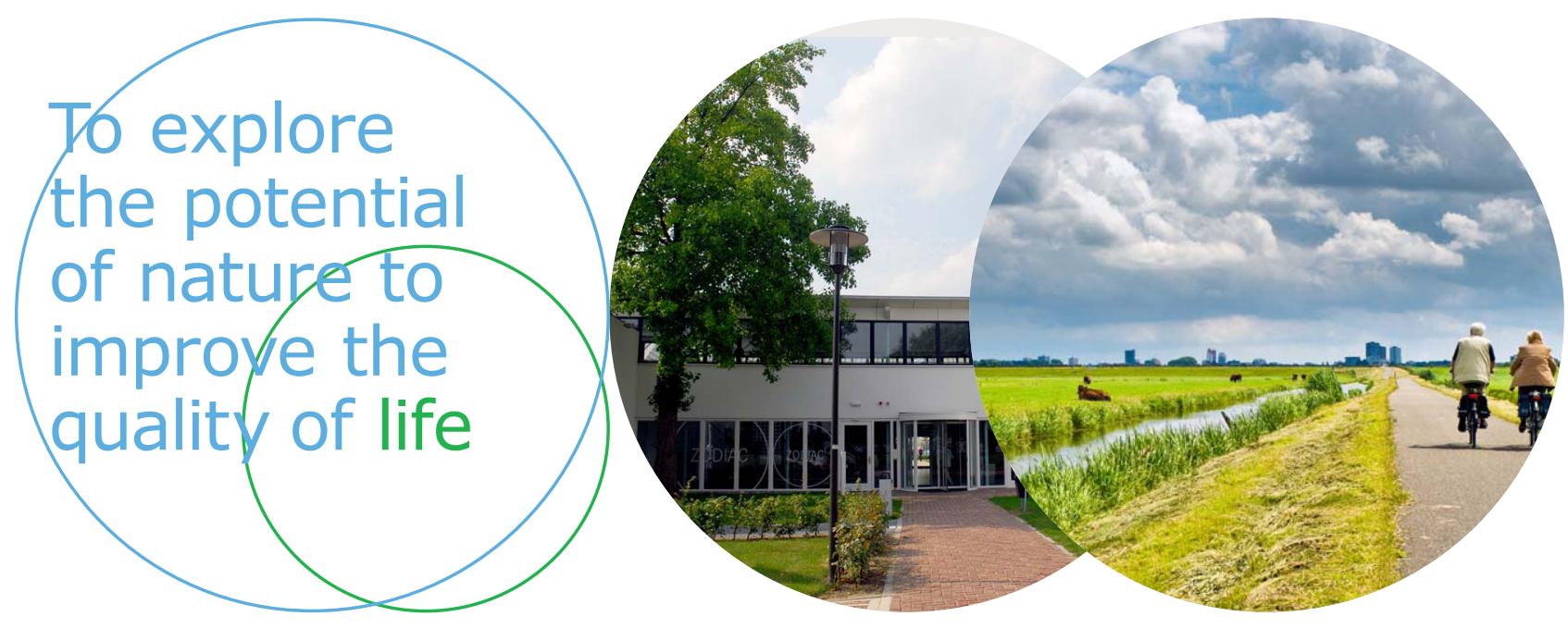

Wageningen Livestock Research Postbus 338 $6700 \mathrm{AH}$ Wageningen

T 0317483953

E info.livestockresearch@wur.nl www.wur.nl/ livestock-research

Wageningen Livestock Research ontwikkelt kennis voor een zorgvuldige en renderende veehouderij, vertaalt deze naar praktijkgerichte oplossingen en innovaties, en zorgt voor doorstroming van deze kennis. Onze wetenschappelijke kennis op het gebied van veehouderijsystemen en van voeding, genetica, welzijn en milieu-impact van landbouwhuisdieren integreren we, samen met onze klanten, tot veehouderijconcepten voor de $21 \mathrm{e}$ eeuw.

De missie van Wageningen University \& Research is 'To explore the potential of nature to improve the quality of life'. Binnen Wageningen University \& Research bundelen 9 gespecialiseerde onderzoeksinstituten van Stichting Wageningen Research en Wageningen University hun krachten om bij te dragen aan de oplossing van belangrijke vragen in het domein van gezonde voeding en leefomgeving. Met ongeveer 30 vestigingen, 6.500 medewerkers en 10.000 studenten behoort Wageningen University \& Research wereldwijd tot de aansprekende kennisinstellingen binnen haar domein. De integrale benadering van de vraagstukken en de samenwerking tussen verschillende disciplines vormen het hart van de unieke Wageningen aanpak. 